Supplement of Biogeosciences, 12, 79-101, 2015

http://www.biogeosciences.net/12/79/2015/

doi:10.5194/bg-12-79-2015-supplement

(C) Author(s) 2015. CC Attribution 3.0 License.

(c) (i)

Supplement of

\title{
Effects of experimental nitrogen deposition on peatland carbon pools and fluxes: a modelling analysis
}

Y. Wu et al.

Correspondence to: C. Blodau (christian.blodau@uni-muenster.de) 
Figure 1 Simulated ratios between annual root and shoot growth $\left(\mathrm{gC} \mathrm{m}^{-2} \mathrm{yr}^{-1}\right)$ (a) and GPP $\left(\mathrm{gC} \mathrm{m}^{-2}\right.$ $\left.\mathrm{yr}^{-1}\right)(\mathrm{b})$ in graminoids with the original parameterization and in modification 3.
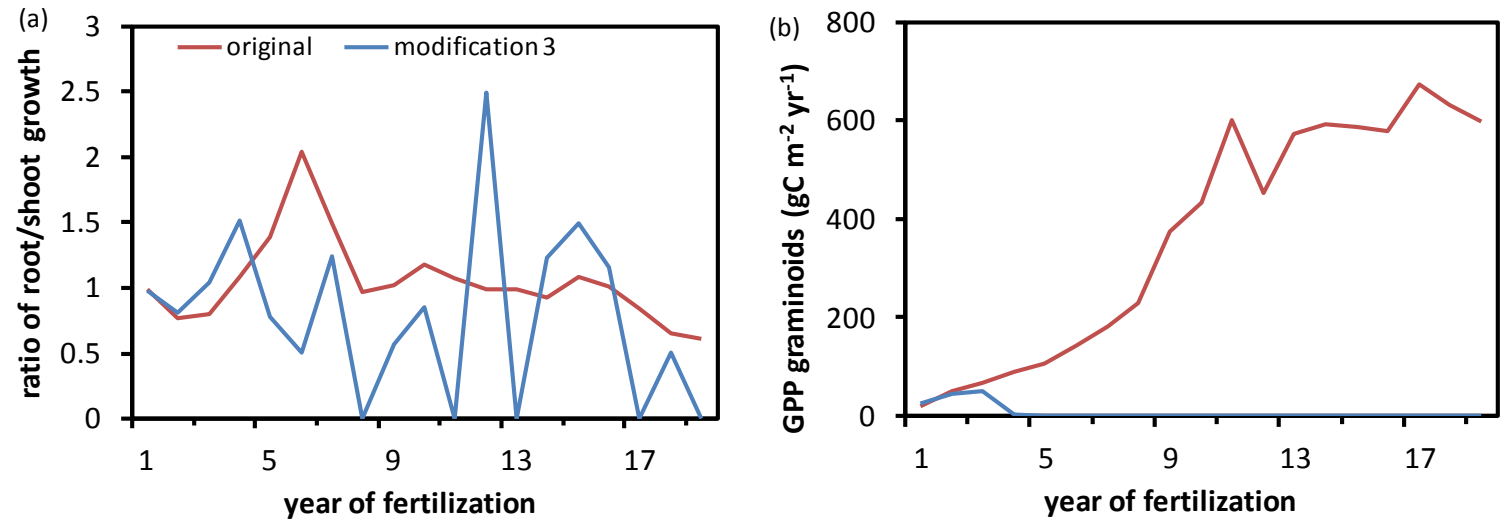

Figure 2 (a) Simulated $\mathrm{C} / \mathrm{N}$ ratio $\left(\mathrm{g} \mathrm{C} \mathrm{g} \mathrm{N}^{-1}\right)$ of the upper $40 \mathrm{~cm}$ peat and the (b) annual average net ecosystem carbon balance (unit: $\mathrm{g} \mathrm{C} \mathrm{m}^{-2} \mathrm{yr}^{-1}$ ) in the Mer Bleue Bog subject to 130 years of fertilization at $6.4 \mathrm{~g} \mathrm{~N} \mathrm{~m}^{-2} \mathrm{yr}^{-1}$.
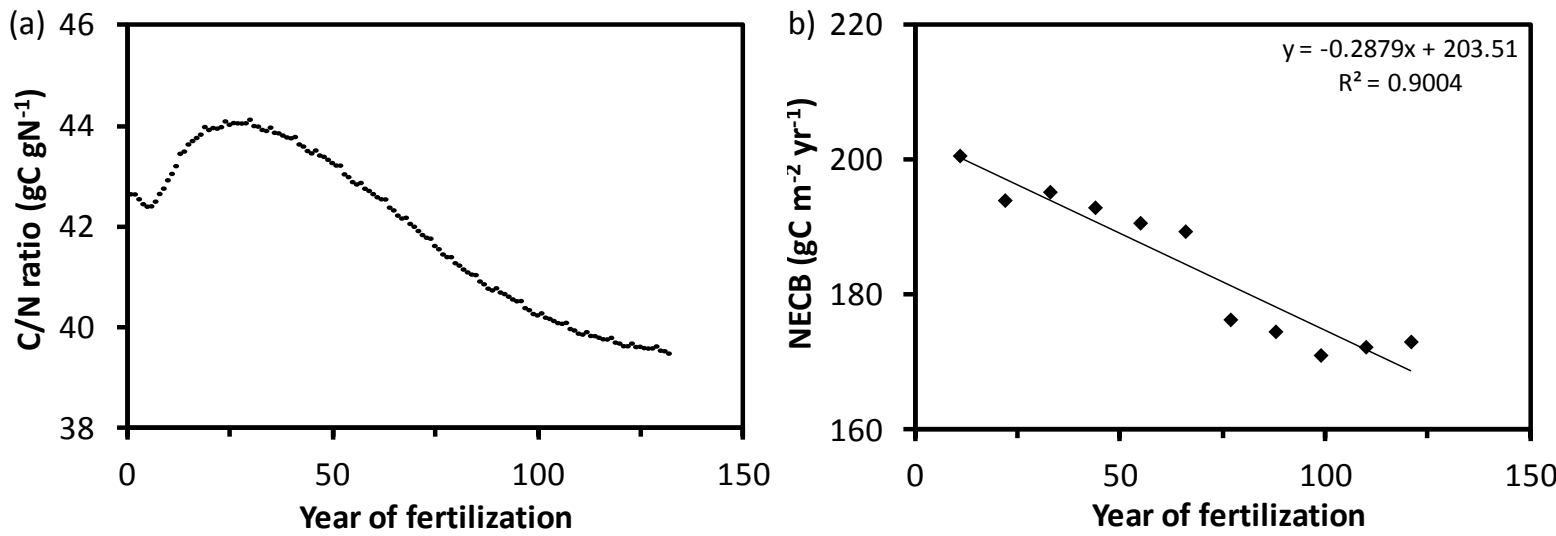
Table 1 The dependency of $\mathrm{GEP}_{\max }$ on leaf $\mathrm{N}$ content in graminoids and shrubs in the original and modified model in Figure 8.

\begin{tabular}{|c|c|c|c|c|c|}
\hline \multirow{2}{*}{$\begin{array}{c}\mathrm{N} \text { content } \\
\left(\mathrm{gN} \mathrm{m}^{-2}\right) \\
\left(\mathrm{N}_{\text {foliar }}\right)\end{array}$} & \multicolumn{3}{|c|}{$\mathrm{N}$ factor on $\mathrm{GEP}_{\max }\left(\mathrm{fN} \mathrm{N}_{\mathrm{GEP}}\right.$ ) for graminoids } & \multicolumn{2}{|c|}{$\mathrm{N}$ factor on GEP $\max$ for shrubs } \\
\hline & $\begin{array}{c}\text { Original and } \\
\text { modification } 1\end{array}$ & Modification $2^{\dagger}$ & Modification $3^{\dagger}$ & Original $^{*}$ & Modification 1 to $3^{\dagger}$ \\
\hline 0 & 0 & 0 & 0 & 0 & 0 \\
\hline 0.25 & 0 & 0 & 0 & 0 & 0.25 \\
\hline 0.5 & 0 & 0 & 0 & 0 & 0.5 \\
\hline 0.75 & 0.325 & 0.038 & 0.038 & 0.167 & 0.335 \\
\hline 1 & 0.55 & 0.25 & 0.25 & 0.333 & 0.21 \\
\hline 1.25 & 0.775 & 0.463 & 0.463 & 0.5 & 0.11 \\
\hline 1.5 & 1 & 0.675 & 0.675 & 0.667 & 0.08 \\
\hline 1.75 & 1 & 0.9 & 0.9 & 0.833 & 0.06 \\
\hline 2 & 1 & 1 & 1 & 1 & 0.05 \\
\hline 2.25 & 1 & 1 & 0.97 & 1 & 0.04 \\
\hline 2.5 & 1 & 0.945 & 0.86 & 1 & 0.035 \\
\hline 2.75 & 1 & 0.825 & 0.01 & 1 & 0.03 \\
\hline 3 & 1 & 0.645 & 0.01 & 1 & 0.025 \\
\hline 3.25 & 1 & 0.5 & 0.01 & 1 & 0.01 \\
\hline 3.5 & 1 & 0.39 & 0.01 & 1 & 0.01 \\
\hline 3.75 & 1 & 0.325 & 0.01 & 1 & 0.01 \\
\hline 4 & 1 & 0.275 & 0.01 & 1 & 0.01 \\
\hline
\end{tabular}

*The original equations of the $\mathrm{N}$ factor on $\mathrm{GEP}_{\max }\left(\mathrm{fN}_{\mathrm{GEP}}\right)$ for graminoids and shrubs are linear:

$$
f N_{G E P}=\left\{\begin{array}{clc}
0 & \text { if } & 0 \leq N_{\text {foliar }}<N_{\text {min }} \\
a N_{\text {foliar }}-b & \text { if } & N_{\text {min }} \leq N_{\text {foliar }}<N_{\text {opt }} \\
1 & \text { if } & N_{\text {opt }} \leq N_{\text {foliar }}
\end{array}\right.
$$

Parameter $a$ and $b$ are the slope and the interception of the linear equation. The values of $a$ and $b$ for the graminoids and the shrubs are listed in Table 2. The parameters of equation 1 are derived from Figure 1 in Hikosaka et al. (2004).

Table 2: Parameter values of GEPmax as a linear function of foliar $\mathbf{N}$ content $\left(\mathbf{N}_{\text {foliar }}\right)$

\begin{tabular}{llll}
\hline Parameter & Description & Graminoids & Shrubs \\
\hline $\mathrm{a}$ & Slope of the linear function & 0.90 & 0.67 \\
$\mathrm{~b}$ & Interception of the linear function & -0.35 & 0.00 \\
$\mathrm{~N}_{\min }\left(\mathrm{gN} \mathrm{m}^{-2}\right)$ & Minimum N content in leaves & 0.50 & 0.00 \\
$\mathrm{~N}_{\text {opt }}\left(\mathrm{gN} \mathrm{m}^{-2}\right)$ & Optimal N content in leaves & 1.50 & 2.00 \\
\hline
\end{tabular}

${ }^{\dagger}$ The modified equations of the $\mathrm{N}$ factors on $\mathrm{GEP}_{\max }$ for graminoids and shrubs are hyperbolic:

$f N_{G E P}=\left\{\begin{array}{ccc}O & \text { if } & 0 \leq N_{\text {foliar }}<N_{\text {min }} \\ 1-\tanh \left(\alpha_{1}\left(N_{\text {opt }}-N_{\text {foliar }}\right) / N_{\text {opt }}\right)^{\beta_{1}} & \text { if } \quad N_{\text {min }} \leq N_{\text {foliar }}<N_{\text {opt }} \\ 1-\tanh \left(\alpha_{2}\left(N_{\text {foliar }}-N_{\text {opt }}\right) / N_{\text {opt }}\right)^{\beta_{2}} & \text { if } \quad N_{\text {opt }} \leq N_{\text {foliar }}<N_{\text {max }} \\ O & \text { if } & N_{\text {max }} \leq N_{\text {foliar }}\end{array}\right.$

Eqn. 2

The curvature parameter $\alpha$ and $\beta$ determines the sensitivity of the photosynthetic capacity (GEP $\max$ ) to the $N$ content in leaves $\left(\mathrm{N}_{\text {foliar }}\right)$. Large values of $\alpha$ indicate low $\mathrm{GEP}_{\max }$ and slow change of GEP $\mathrm{P}_{\text {max }}$ approaching the minimum and the highest $\mathrm{N}$ content $\left(\mathrm{N}_{\min }\right.$ and $\left.\mathrm{N}_{\max }\right)$. Large values of $\beta$ indicate slow change of GEP $\mathrm{P}_{\max }$ approaching the optimal $\mathrm{N}$ content $\mathrm{N}_{\mathrm{opt}}$. For example, larger $\alpha_{2}$ and $\beta_{2}$ in Modification 3 than in Modification 2 for graminoids imply a faster decline of GEP $\max$ above the $\mathrm{N}_{\text {opt }}$ in modification 3. The minimum and optimal foliar $\mathrm{N}$ content for photosynthesis is lower in the shrubs than in the graminoids, indicating that shrubs are more limited to $\mathrm{N}$ and more conservative in their $\mathrm{N}$ consumption. The parameter values in equation 2 for the modifications are shown in Table 3. 
Table 3: Parameter values of GEPmax as hyperbolic functions of foliar $\mathbf{N}$ content $\left(\mathbf{N}_{\text {foliar }}\right)$

\begin{tabular}{lllll}
\hline Parameter & Description & $\begin{array}{l}\text { Graminoids } \\
\text { Modification 2 }\end{array}$ & $\begin{array}{l}\text { Graminoids } \\
\text { Modification 3 }\end{array}$ & $\begin{array}{l}\text { Shrubs } \\
\text { Modification 1 to 3 }\end{array}$ \\
\hline$\alpha_{1}$ & Curvature parameter & 4 & 3 & 2 \\
$\beta_{1}$ & Curvature parameter & 8 & 2.5 & 2 \\
$\alpha_{2}$ & Curvature parameter & 1.5 & 4 & 1 \\
$\beta_{2}$ & Curvature parameter & 1.7 & 8 & 2 \\
$\mathrm{~N}_{\min }$ & Minimum N content in leaves & 0.5 & 0.5 & 0 \\
$\mathrm{~N}_{\max }$ & Maximum N content in leaves & $/$ & 2.5 & 1 \\
$\mathrm{~N}_{\text {opt }}$ & Optimal N content in leaves & 2.2 & 2 & 0.5 \\
\hline
\end{tabular}

\section{Conceptual relations between GEPmax and leaf $\mathrm{N}$ content}

Based on Table 2, a relation between $\mathrm{GEP}_{\max }$ and leaf $\mathrm{N}$ content can be expressed as:

$G E P_{\text {max }}=\tanh \left(\frac{\alpha\left|N_{\text {opt }}-N_{\text {foliar }}\right|}{N_{\text {opt }}}\right)^{\beta}$

The $\mathrm{N}_{\text {opt }}$ represents the optimal $\mathrm{N}$ level in the leaves for the photosynthetic capacity. The curvature parameters $\alpha$ and $\beta$ determine the sensitivity of the photosynthetic capacity $\left(G E P_{\max }\right)$ to the $\mathrm{N}$ content in leaves $\left(\mathrm{N}_{\text {foliar }}\right)$. Large values of $\alpha$ indicate low GEP $P_{\max }$ and slow change of GEP $P_{\max }$ approaching the low and high end of $N$ content. Large values of $\beta$ indicate slow change of GEP $\max$ approaching the optimal $N$ content $N_{\text {opt. }}$. Small $\alpha$ and large $\beta$ values characterize a high ability utilize foliar $N$ on photosynthesis and vise verse. While the $N_{\text {opt }}$ level has been often identified from empirical data, $\alpha$ and $\beta$ values are highly uncertain. In order to predict the effect of $N$ on $C$ fluxes and vegetation in peatlands, the $\alpha$ and $\beta$ parameters need to be determined for different PFTs and a growth strategy to be identified.

\section{relation between GEPmax and $\mathrm{N}$ content}

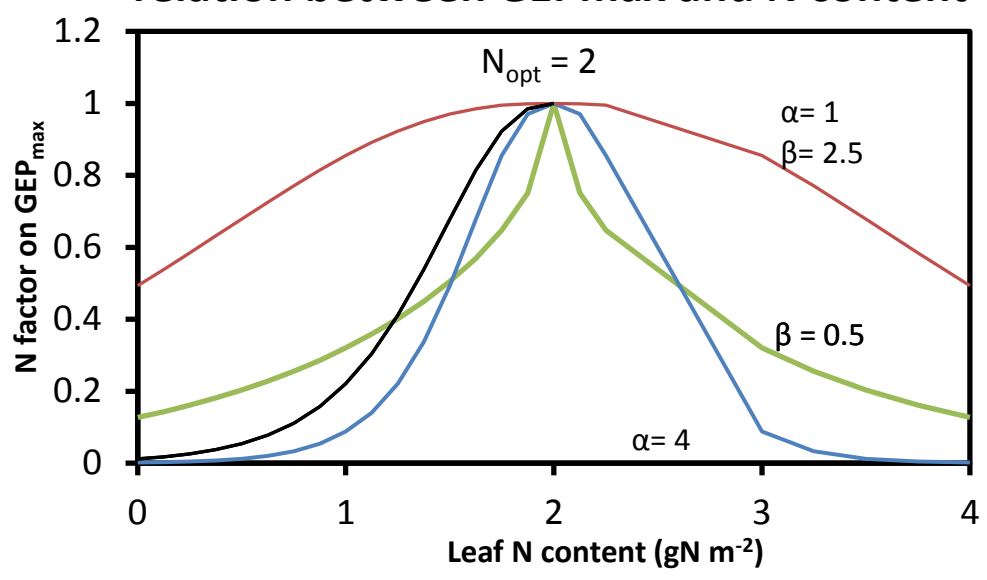

References:

Hikosaka, K.: Interspecific difference in the photosynthesis-nitrogen relationship: patterns, physiological causes, and ecological importance, Journal of Plant Research, 117, 481-494, 10.1007/s1 0265-004-0174-2, 2004. 